\title{
FLAVONOID AGLYCONS IN FOODS OF PLANT ORIGIN I. VEGETABLES
}

\author{
A. LUGASI and J. HóvÁRI \\ József Fodor National Center of Public Health, National Institute of Food Hygiene and Nutrition, \\ H-1097 Budapest, Gyáli út 3/a. Hungary
}

(Received: 7 February 2000, accepted: 11 May 2000)

\begin{abstract}
The content of the potentially health-defensive and disease-preventive flavonoids quercetin, kaempferol, myricetin, apigenin and luteolin of 31 vegetables were determined by RPHPLC with UV detection. Vegetables were purchased at the local markets in Budapest at a period of their most frequent consumption. Quercetin levels in the edible parts of most vegetables were generally below $10 \mathrm{mg} \mathrm{kg}^{-1}$, except for onions $\left(67-121.5 \mathrm{mg} \mathrm{kg}^{-1}\right)$, lettuce $\left(13.5-35.0 \mathrm{mg} \mathrm{kg}^{-1}\right)$, dill $\left(74.5 \mathrm{mg} \mathrm{kg}^{-1}\right)$, broccoli $\left(15.5 \mathrm{mg} \mathrm{kg}^{-1}\right)$ and spinach $\left(272.2 \mathrm{mg} \mathrm{kg}^{-1}\right)$. Kaempferol was below $30 \mathrm{mg} \mathrm{kg}^{-1}$ except for parsnip $\left(66.4 \mathrm{mg} \mathrm{kg}^{-1}\right)$ and leek $\left(45.8 \mathrm{mg} \mathrm{kg}^{-1}\right)$. Myricetin could only be detected in lettuce, Swedish turnip, parsley and celery leaves, and dill. Detectable amount of luteolin was in radishes, some representatives of Brassica, sweet peppers, celery leaves and spinach while apigenin was only in Swedish turnip, celery root and celery leaves. These data provide a basis for the evaluation of the average daily intake of Hungarian population and for an epidemiological evaluation of health-promoting effects of flavonoids.
\end{abstract}

Keywors: flavonoid aglycons, vegetables

Flavonoids are ubiquitous in all plant organs and are, therefore, an integral part of the human diet. Flavonoids are widespread secondary plant metabolites and are found at high levels in many plant foods and beverages. Their common structure is that of diphenylpropanes $\left(\mathrm{C}_{6}-\mathrm{C}_{3}-\mathrm{C}_{6}\right)$ and consists of two aromatic rings linked through three carbons that usually form an oxygenated heterocycle (BRAVO, 1998). Flavonoids occur in foods generally as $\mathrm{O}$-glycosides with sugars bound usually at the $\mathrm{C} 3$ position. Flavonoids consist mainly of anthocyanins, flavonols, flavones, catechins, isoflavonoids and flavanes (HERMANN, 1988). Although flavonoids are generally considered to be non-nutritive agents, interest in these substances has arisen because of possible effects on human health. Researchers demonstrated a wide range of biochemical and pharmacological effects, including anti-inflammatory, and antiallergic effect (MANACH et al., 1996, HerToG, 1996). Food derived flavonoids such as the flavonol quercetin, kaempferol and myricetin have antimutagenic and anticarcinogenic effects in vitro and in vivo (Verma et al, 1988, DESCHNER et al., 1991, DuthiE et al., 1997 a, b, 1999, 
KUNTZ et al., 1999). Epidemiological researches on the relation between flavonoid intake and risk of cardiovascular diseases pointed out the protective effect of the consumption of vegetables and fruits having significant amount of flavonoids (MELTZER \& MALterud, 1997, KatAN \& HOllman, 1998, HertOG et al., 1995).

Total flavonoid intake in the US was estimated to be around $1 \mathrm{~g} /$ day, of which about $100 \mathrm{mg}$ (expressed as aglycones) consisted of flavonols and flavones (KÜHNAU, 1976). These estimates were based on food composition data, which may have been inaccurate and incomplete. HERTOG and co-workers (1993b) calculated the intake of two types of flavonoids, flavonols and flavones in the Dutch diet, and found it to be $23 \mathrm{mg}$ /day. This figure is significantly smaller than KÜHNAU's (1976) estimation of $115 \mathrm{mg} /$ day for these two flavonoids, which is allegedly overestimated because of the unreliability of the analytical method employed during the 1970s. The main food sources of the flavonoids in the Netherlands were black tea ( $48 \%$ of total intake), onions $(29 \%)$ and apples (7\%). More recently, LETH and JUSTESEN (1998) estimated the intake of flavones, flavonols, and flavonones in Denmark to be $28 \mathrm{mg} /$ day. KUMPULAINEN and co-workers (1999) reported that the total average intake of 23 different flavonoid aglycons in Finland based on their food composition data was $55.2 \mathrm{mg} /$ day, where fruits contributed $36.5 \mathrm{mg} /$ day followed by tea, wine and other, non-alcoholic beverages $(13.9 \mathrm{mg} /$ day, vegetables $(2.9 \mathrm{mg} /$ day $)$ and berries $(2.0 \mathrm{mg} /$ day $)$.

On the basis of data from the literature (HERTOG et al, 1992b, 1993a, KuMPULAINEN, 1999) we selected three major flavonols, quercetin, kaempferol, and myricetin, and two major flavones, luteolin and apigenin because these flavonoids are the most widely investigated in animal and human studies for their beneficial health effects. We adapted an HPLC method for the identification and quantification of these flavonoids in freeze-dried foods. We have now measured the content of these flavonoids in 31 vegetables commonly consumed in Hungary. We have also intended to compare the Hungarian analytical data to Dutch ones published by HERTOG and co-workers (1992b).

\section{Materials and methods}

\subsection{Chemicals}

Quercetin, luteolin, myricetin, kaempferol and t-butylhydroquinone were purchased from Sigma, apigenin from Fluka and methanol of chromatography grade was obtained from Merck. All other chemicals and reagents were of analytical grade from Reanal (Hungary). 


\subsection{Vegetables}

Thirty-one selected fresh vegetables $(1 \mathrm{~kg}$, or a minimum of three units) were purchased from 3 different stallkeepers in the local markets in Budapest at a period of their most frequent consumption. The edible parts of the vegetables were used for the examination, and samples from three locations were combined. After buying, the samples were immediately cleaned, chopped into small pieces and freeze-dried. After lyophilization, samples were allowed to equilibrate in open air and ground to pass a $0.5 \mathrm{~mm}$ sieve. Moisture was measured by drying at $105^{\circ} \mathrm{C}$. The food samples were stored at $-18{ }^{\circ} \mathrm{C}$ for less than 4 months until analyzed.

\subsection{HPLC analysis}

The flavonols (quercetin, kaempferol, myricetin) and the flavones (apigenin, luteolin) were measured as aglycons according to HERTOG and co-workers (1992a). Briefly, flavonoid glycosides were extracted and hydrolyzed to their aglycons with $6.0 \mathrm{~N}$ $\mathrm{HCl}$ in boiling $62.5 \%$ aqueous methanol in the presence of $0.1 \mathrm{~g} t$-butylhydroquinone for two hours. After refluxing the extract was allowed to cool and was subsequently made up to $50 \mathrm{ml}$ with methanol and sonicated for $5 \mathrm{~min}$. Approximately $2 \mathrm{ml}$ was filtered through $0.45 \mu \mathrm{m}$ filter (Chromafil AO-20/25) before injection. The resulting aglycons were quantified by RP-HPLC (Perkin Elmer) on a Premisphere $\mathrm{C}_{18}$ column $(150 \times 3.9 \mathrm{~mm}, 5 \mu \mathrm{m}$, Phenomenex, USA) using methanol/phosphate buffer $(45: 55 \mathrm{v} / \mathrm{v}$, $\mathrm{pH} 2.4)$, as a mobile phase and UV detection $(365 \mathrm{~nm})$.

Limit of detection was defined as the amount of flavonoids resulting in a peak height of 3 times higher than the standard deviation of the baseline noise. Peak identification was confirmed with the use of known retention time of pure flavonoids. Quantification of the flavonoids was done by peak area measurement. Calibration curves of individual flavonoids were made over a range of $5-20 \mu \mathrm{g} \mathrm{ml}^{-1}$. Detector response was linear over the concentration range used. For all standards $r^{2}$ was higher than 0.998 .

\section{Results and discussion}

Tables 1-4 report the flavonoid content of the fresh vegetables $\left(\mathrm{m} \mathrm{kg}^{-1}\right)$. Quercetin and kaempferol are proved to be the most widespread flavonoids in vegetables. Our present results are similar to HERTOG and co-workers' observations (1992b) but there are some minor differences in relation of the quality and quantity of the compounds, as well. Quercetin levels in the edible parts of most vegetables were generally below $10 \mathrm{mg} \mathrm{kg}^{-1}$. The highest quercetin concentration could be detected in spinach $\left(272.2 \mathrm{mg} \mathrm{kg}^{-1}\right)$ and in the different types of onion $\left(67.1-171.3 \mathrm{mg} \mathrm{kg}^{-1}\right)$. HERTOG and co-workers (1992b) could not measure any quercetin in spinach. High 
quercetin level was also found in dill $\left(74.5 \mathrm{mg} \mathrm{kg}^{-1}\right)$, crisped lettuce $\left(35.0 \mathrm{mg} \mathrm{kg}^{-1}\right)$, and broccoli $\left(15.4 \mathrm{mg} \mathrm{kg}^{-1}\right)$. Very low level or no quercetin was detected in different root vegetables such as celery and beet root, radishes and also in Brassica vegetables except broccoli.

Significant amount of kaempferol was observed in parsnip $\left(66.4 \mathrm{mg} \mathrm{kg}^{-1}\right)$, leek (45.8 $\mathrm{mg} \mathrm{kg}^{-1}$ ), fresh onion collected in early summer $\left(34.3 \mathrm{mg} \mathrm{kg}^{-1}\right)$, and broccoli $\left(30.8 \mathrm{mg} \mathrm{kg}^{-1}\right.$ ). Average level of flavonoid could be detected in other Brassica and root vegetables. Practically there was no kaempferol in leafy vegetables except crisped lettuce $\left(8.4 \mathrm{mg} \mathrm{kg}^{-1}\right)$. In the study of HERTOG and co-workers (1992b) kaempferol was found in kale $\left(211 \mathrm{mg} \mathrm{kg}^{-1}\right)$, endive $\left(46 \mathrm{mg} \mathrm{kg}^{-1}\right)$, leek $\left(30 \mathrm{mg} \mathrm{kg}^{-1}\right)$, and turnip tops $\left(48 \mathrm{~m} \mathrm{~kg}^{-1}\right)$. In some other vegetables such as Brussels sprouts, French been, radish and broad bean very little low levels were published. Authors mentioned above could not find any kaempferol in onions, cauliflower, white cabbage, tomato and Swedish turnip while we detected significant amount in these vegetables.

The flavonol myricetin was found in only five vegetables, namely Swedish turnip (85.4 $\mathrm{mg} \mathrm{kg}^{-1}$ ), parsley leaves $\left(80.8 \mathrm{mg} \mathrm{kg}^{-1}\right)$, celery leaves $\left(43.4 \mathrm{mg} \mathrm{kg}^{-1}\right)$, lettuce $\left(10.1 \mathrm{mg} \mathrm{kg}^{-1}\right)$, and dill $\left(7.0 \mathrm{mg} \mathrm{kg}^{-1}\right)$. Regrettable the leaves of parsley, celery and dill are consumed as a condiment in special Hungarian dishes, therefore, the participation of these vegetables in the flavonoid intake of the population is probably negligible. Based on HERTOG's observation (1992b) only fresh broad bean can be considered as a natural source of myricetin, but its concentration is low $\left(26 \mathrm{mg} \mathrm{kg}^{-1}\right)$.

Table 1

Flavonoid concent a of leafy vegetables

\begin{tabular}{lcccccc}
\hline Sample & Quercetin & Kaempferol & Myricetin & Luteolin & Apigenin & $\begin{array}{c}\text { Total } \\
\text { flavonoids }\end{array}$ \\
\hline Lettuce & 16.3 & nd $^{\mathrm{b}}$ & 10.2 & nd & nd & 26.5 \\
Crisped lettuce & 35.0 & 8.4 & nd & 3.9 & nd & 47.3 \\
Ice lettuce & 13.5 & nd & nd & nd & nd & 13.5 \\
Spinach & 272.2 & nd & nd & 66.4 & nd & 338.6 \\
Parsley leaves & nd & nd & 80.8 & nd & nd & 80.8 \\
Celery leaves & nd & nd & 43.4 & 111.4 & nd & 154.8 \\
Dill & 74.5 & nd & 7.0 & nd & nd & 81.5 \\
\hline
\end{tabular}

${ }^{a}$ Mean ( $\mathrm{mg} \mathrm{kg}^{-1}$ of fresh edible part) of duplicate determination.

${ }^{\mathrm{b}}$ Below the detection limit. 
Table 2

Flavonoid content ${ }^{a}$ of root vegetables

\begin{tabular}{|c|c|c|c|c|c|c|}
\hline Sample & Quercetin & Kaempferol & Myricetin & Luteolin & Apigenin & $\begin{array}{c}\text { Total } \\
\text { flavonoids }\end{array}$ \\
\hline Purple radish & $n d^{b}$ & 10.5 & nd & nd & nd & 10.5 \\
\hline Black radish & nd & 21.1 & nd & d & nd & 21.1 \\
\hline Horse radish & 5.7 & 25.7 & nd & 9.0 & nd & 31.4 \\
\hline Red beet & 6.7 & nd & nd & 18.3 & nd & 25.0 \\
\hline Carrot & 3.5 & nd & nd & nd & nd & 3.5 \\
\hline Parsnip & 9.9 & nd & nd & nd & nd & 9.9 \\
\hline Celery root & 1.8 & nd & nd & nd & 24.1 & 25.9 \\
\hline Swedish turnip & 3.2 & 22.7 & 85.4 & nd & 154.0 & 265.3 \\
\hline
\end{tabular}

${ }^{\text {a }}$ Mean ( $\mathrm{mg} \mathrm{kg}^{-1}$ of fresh edible part) of duplicate determination.

${ }^{\mathrm{b}}$ Below the detection limit.

Table 3

Flavonoid content ${ }^{a}$ of Brassica vegetables

\begin{tabular}{lcccccc}
\hline Sample & Quercetin & Kaempferol & Myricetin & Luteolin & Apigenin & $\begin{array}{c}\text { Total } \\
\text { flavonoids }\end{array}$ \\
\hline Cauliflower & 1.5 & 12.5 & nd $^{\text {b }}$ & 4.0 & nd & 18.0 \\
Broccoli & 15.4 & 30.8 & nd & nd & nd & 46.2 \\
Kohlrabi & 4.0 & 24.3 & nd & 13.0 & nd & 41.3 \\
Brussel sprouts & nd & 12.8 & nd & 6.7 & nd & 19.5 \\
Kale & nd & 4.8 & nd & nd & nd & 4.8 \\
Chinese cabbage & nd & 7.3 & nd & nd & nd & 7.3 \\
White cabbage & 1.6 & 11.9 & nd & 4.2 & nd & 17.7 \\
Red cabbage & 9.2 & nd & nd & 6.3 & nd & 15.5 \\
\hline
\end{tabular}

${ }^{\text {a }}$ Mean $\left(\mathrm{mg} \mathrm{kg}^{-1}\right.$ of fresh edible part) of duplicate determination.

${ }^{\mathrm{b}}$ Below the detection limit.

Significant amount of flavon luteolin could be detected in celery leaves $\left(111.4 \mathrm{mg} \mathrm{kg}^{-1}\right)$, spinach $\left(66.4 \mathrm{mg} \mathrm{kg}^{-1}\right)$, red beet $\left(18.3 \mathrm{mg} \mathrm{kg}^{-1}\right)$, kohlrabi (13.0 mg kg-1$)$, and different types of sweet pepper (10.7-11.3 mg kg-1). HERTOG and co-workers (1992b) could find luteolin only in red bell pepper $\left(11 \mathrm{mg} \mathrm{kg}^{-1}\right)$. 
Table 4

Flavonoid content ${ }^{a}$ of onions, sweet peppers and other vegetables

\begin{tabular}{lcccccc}
\hline Sample & Quercetin & Kaempferol & Myricetin & Luteolin & Apigenin & $\begin{array}{c}\text { Total } \\
\text { flavonoids }\end{array}$ \\
\hline Onion (old) & 121.5 & 2.6 & $\mathrm{nd}^{\mathrm{b}}$ & nd & nd & 124.1 \\
Onion (young) & 67.1 & 34.5 & nd & nd & nd & 101.6 \\
Red onion & 171.3 & 24.3 & nd & nd & nd & 195.6 \\
Leek & 5.0 & 45.8 & nd & nd & nd & 50.8 \\
Sweet pepper & 9.4 & nd & nd & 10.7 & nd & 20.1 \\
Californian pepper & 5.1 & nd & nd & 11.3 & nd & 16.4 \\
Tomato & 2.7 & 8.4 & nd & nd & nd & 11.1 \\
Cucumber & 2.4 & 3.3 & nd & nd & nd & 5.7 \\
\hline
\end{tabular}

${ }^{a}$ Mean ( $\mathrm{mg} \mathrm{kg}^{-1}$ of fresh edible part) of duplicate determination.

${ }^{\mathrm{b}}$ Below the detection limit.

Apigenin was detected in celery leaves $\left(248.0 \mathrm{mg} \mathrm{kg}^{-1}\right)$, Swedish turnip (154.0 m kg ke $)$, and celery root $\left(24.1 \mathrm{mg} \mathrm{kg}^{-1}\right)$. HERTOG and colleagues (1992b) reported apigenin only in celery $\left(108 \mathrm{mg} \mathrm{kg}^{-1}\right)$. In a Danish survey in celery leaves apigenin $\left(740 \mathrm{mg} \mathrm{kg}^{-1}\right)$ and luteolin $\left(200 \mathrm{mg} \mathrm{kg}^{-1}\right)$ were found, and in parsley apigenin (1850 $\mathrm{mg} \mathrm{kg}^{-1}$ ) was detected (LETH \& JUSTESEN, 1998).

In the present investigation all vegetables had significant amount of flavonols and/or flavones. The best sources of selected five flavonoids were spinach (338.6 mg kg-1), Swedish turnip (265.3 $\mathrm{m} \mathrm{kg}^{-1}$ ), red, young and old onions (195.6, 124.1, and $101.6 \mathrm{mg} \mathrm{kg}^{-1}$, respectively), and celery leaves $\left(154.8 \mathrm{mg} \mathrm{kg}^{-1}\right)$. As the formation of flavonoids is light dependent, flavonoids occur predominantly in the leaves. In contrast, the concentration of flavonoids is low ( $<1 \mathrm{mg} \mathrm{kg}^{-1}$ fresh weight) in roots or tubercules; but in some cases these compounds may accumulate in the underground parts of certain plants such as onions and radishes. No vegetables were found free from flavonoids. Opposite of our observations, HERTOG and co-workers (1992b) could not detect any of the flavonoids in spinach, red beet, cucumber, carrot and some of Brassicca vegetables such as sauerkraut, white cabbage, Swedish turnip, and green cabbage. In general, our values are somewhat higher than those reported earlier by HERMANN (1976) and by HERTOG and co-workers (1992b). These discrepancies may be due to different cultivars, varietal and seasonal differences. 


\section{Conclusion}

The large group of plant polyphenols attracts major interest because of their potential anticarcinogenic and other beneficial properties, presumably based on their function as natural antioxidants. Otherwise the flavonoids are compounds of particular interest because of their high prevalence in foodstuffs. Our investigation proves the presence of singificant amount of different flavonoids in selected vegetables frequently consumed in Hungary. These investigations are a part of our study on a national database of flavonoids in foodstuffs and help to discover the main sources of flavonoids and the estimation of average daily intake of quercetin, myricetin, luteolin, apigenin, and kaempferol in different groups in the Hungarian population.

This study was supported by the Ministry of Welfare (ETT 052/1996), Hungary. The support was initially given to Prof. E. DWORSCHÁK who unexpectedly deceased during this research. This work was performed in his unforgettable memory.

\section{References}

BRAVO, L. (1998): Polyphenols: Chemistry, dietary sources, metabolism, and nutritional significance. Nutr. Rev., 56, 317-333.

DESCHNER, E. E., RUPERTO, J., WONG, G. \& NEWMARK, H. L. (1991): Quercetin and rutin as inhibitors of azoxymethanol-induced colonic neoplasia. Carcinogenesis, 7, 1193-1196.

DuTHIE, S. J., JOHNSON, W. \& DOBSON, V. L. (1997a): The effect of dietary flavonoids on DNA damage (strand breaks and oxidised pyrimidines) and growth in human cells. Mutat. Res., 390, 141-145.

DuThie, S. J., COllins, A. R., DUTHIE, G. G. \& DOBSON, V. L. (1997b): Quercetin and myricetin protect against hydrogen peroxide-induced DNA damage (strand breaks and oxidised pyrimidines) in human lymphocytes. Mutat. Res., 393, 223-231.

HERMANN, K. (1976): Flavonols and flavones in food plants: a review. J. Fd Technol., 11. 433-448.

HERMANN, K. (1988): On the occurrence of flavonol and flavone glycosides in vegetables. Z. Lebensm. Unters. Forsch., 186, 1-5.

HERTOG, M. G. L. (1996): Epidemiological evidence on potential health properties of flavonoids. Proc. Nutr. Soc., 55; 385-397.

HertoG, M. G. L., HOLlman, P. C. H. \& VENEMA, D. P. (1992a): Optimalization of a quantitative HPLC determination of potentially anticarcinogenic flavonoids in vegetables and fruits. J. agric. Fd Chem., 40, 1591-1598.

HertoG, M. G. L., HOLlman, P. C. H. \& KATAN, M. B. (1992b): Content of potentially anticarcinogenic flavonoids of 28 vegetables and 9 fruits commonly consumed in The Netherlands. J. agric. $F d$ Chem., 40, 2379-2383. 
HeRTOG, M. G. L., HOllman, P. C. H. \& VAN De PRUTTE, B. (1993a): Content of potentially anticarcinogenic flavonoids of tea infusions, wines, and fruit juices. J. agric. Fd Chem., 41, $1242-1246$

HeRTOG, M. G. L., HOLlman, P. C. H., KATAN, M. B. \& KROMHOUT, D. (1993b): Intake of potentially anticarcinogenic flavonoids and their determinants in adults in Netherlands. Nutr. Cancer, 20, 21-29.

HERTOG, M. G. L., KROMHOUT, D., ARAVANIS, C., BLACKBOURN, H., BUZINA, R., FidANZA, F., GIAMPAOLI, S., JanSen, A., MenotTi, A., NedelJKovic, S., PekKarinen, M., Simic, B. S., TOShiMA; H., FESKENS, E. J. M, HOLLMAN, P. C. H. \& KATAN, M. B. (1995): Flavonoid intake and long-term risk of coronary heart disease and cancer in the Seven Countries Study. Arch. int. Med., 155, 381-386.

KATAN, M. B. \& HOLLMAN, P. C. H. (1998): Dietary flavonoids and cardiovascular disease. Nutr. Metab. Cardiovasc. Dis., 8, 1-4.

KumpulainEN, J. T., LEHTONEN, M. \& MATTILA, P. (1999).: Trolox equivalent antioxidant capacity of average flavonoids intake in Finland.-in: KUMPULAINEN, J. T. \& SALONEN, J. T. (Eds) Natural antioxidants and anticarcinogens in nutrition, health and disease. The Royal Society of Chemistry, Cambridge, UK, pp. 141-150.

KUNTZ, S., WENZEL, U. \& DANIEL, H. (1999): Comparative analysis of the effects of flavonoids on proliferation, cytotoxicity, and apoptosis in human colon cancer cell lines. Eur. J. Nutr., 38, $133-142$.

KÜHNAU, J. (1976): The flavonoids: a class of semi-essential food components: their role in human nutrition. World Rev. Nutr. Diet., 24, 117-120.

LETH, T. \& JUSTESEN, U. (1998): Analysis of flavonoids in fruits, vegetables and beverages by HPLC-UV and LC-MS and estimation the total daily flavonoid intake in Denmark. in: AMADO, R., ANDERSSON, H., BARDÓCZ, S. \& SERRA, F. (Eds) Polyphenols in food. Office for Official Publications of the European Communities Luxembourgh: pp. 39-40.

MANACH C., REgERAT, F., TeXIER, O., AgUllo, G., Demigne, C. \& REMESy, C. (1996): Bioavailability, metabolism and physiological impact of 4-oxo-flavonoids. Nutr. Res., 16, 517-544.

MELTZER, H. M. \& MALTERUD, K. E. (1997): Can dietary flavonoids influence the development of coronary heart disease? Scan. J. Nutr., 41, 50-57.

VERMA, A. K., JOHNSON, J. A., GOULD, M. N. \& TANNER, M. A. (1988): Inhibition of 7,11dimethylbenz(a)anthracene and $\mathrm{N}$-nitrosomethylurea induced rat mammary cancer by dietary flavonol quercetin. Cancer Res., 48, 5754-5788. 